\title{
Diurnal variation in the feeding patterns and food preferences of Dwarf panchax (Aplocheilus parvus)
}

\author{
G.K.A.W. Fernando ${ }^{1}$, S. Jayakody*1, W.M.H.K. Wijenayake ${ }^{1}$, G.N.L. \\ Galappaththy $^{2}$, M. Yatawara ${ }^{3}$, R.D.J. Harishchandra ${ }^{2}$, W.M.T.B. \\ Wanninayake $^{1}$ and S.L. Deniyage ${ }^{2}$
}

${ }^{1}$ Department of Aquaculture and Fisheries, Wayamba University of Sri Lanka, Makandura, Gonawila, Sri Lanka, ${ }^{2}$ Anti-Malaria Campaign, Colombo 05, Sri Lanka, ${ }^{3}$ Department of Zoology and Environment Management, University of Kelaniya, Kelaniya, Sri Lanka,

*Corresponding Author: sevvandi_jayakody@yahoo.com

\begin{abstract}
The food and feeding studies of fish are useful to explore the possibilities of using them for various purposes such as aquaculture and biological control of problematic organisms. In the current study feeding patterns and diet composition of Aplocheilus parvus (E: Killi fish/Drawft panchax), a common surface feeding predator inhabiting freshwater systems were explored. A. parvus was collected from an abandoned brick pit in Pannala in 2012. Twelve fish were caught every two hours for 24 hours. Plankton net was used to obtain a representative sample of food items present in the system. Gut fullness, total and standard length of fish, total weight and gut weight were determined and using copepod as an arbitrary unit, total numbers of food items of individual fishes were estimated. The time at which active feeding occurred was established from total food particle amount and relative gut weight. Diet of A. parvus mainly consisted of adult or larval stages of insects and copepods. Also, gut had a higher fullness in day time compared to night. The peak gut fullness occurred during 1630 in males whilst females had the peak gut fullness at 1230. Copepods were detected mostly during late morning, whilst insect parts and coleopterans were present in all time periods. Main food items detected in the environment in descending order of abundance were copepods, filamentous algae and insects. This study demonstrated that $A$. parvus selectively preys on insects compared to other aquatic food sources during day time.
\end{abstract}

Keywords: Aplocheilus parvus, biological control, Drawft panchax, gut analysis, insects 


\section{Introduction}

Diverse food habits among different fish species are responsible for effective utilization of available food items in the natural environments to manage the carrying capacity (Kumar et al. 2012). Extensive studies have been conducted on food and feeding habits of economically and ecologically important fish species (Johnson and Dropkin 1993; Alkahem et al. 2007). Food and feeding also reveal species interactions (Sivadas and Bhaskaran 2009), prey selectivity (Zandona et al. 2011) prey-predator relationships and ontogenitic trophic shifts (Day et al. 2011). As such, fish stock assessment, ecosystem modeling (Lopez-Peralta and Arcila 2002; Kumar and Hwang 2006) and community ecology studies (Shallof and Khalifa 2009) depend on broad knowledge regarding this aspect of fish. Further, understanding the food and feeding of fish is also used in algal control programmes (Xie 2001), aquaculture and fisheries management practices (Awasthi et al. 2006; Banaru and Harmelin-Vivien 2009) and biological control such as mosquitoes (Louca et al. 2009; Kweka et al. 2011).

Diverse fish assemblages are distributed in a variety of lentic and lotic freshwater habitats throughout Sri Lanka (Jayaratne and Surasinghe 2010; Goonathilake 2012). Up to now 91 freshwater fish species have been recorded, which consist of 50 endemics and 24 exotics (Goonathilake 2012). Amongst these species, attention has recently been directed towards surface dwelling predatory fish species and their feeding, since Sri Lanka is looking for alternatives to control vectors such as mosquito larvae of some diseases such as malaria and dengue (Konradsen et al. 2000).

Of known predatory fish, killifish or panchax (Order: Cyprinodontiformes, Family: Aplocheilidae) such as A. panchax (blue panchax), A. lineatus (striped panchax) (Frenkel and Goren 2000; Chandra et al. 2008) are used elsewhere. However, feasibility of such approaches in Sri Lanka is hindered by lack of systematic studies on their feeding. Killfish species found in Sri Lankan water bodies are Aplocheilus parvus, A. dayi and A. werneri. A.dayi and A.werneri are endemic while the smallest $A$. parvus is indigenous and relatively common (Pethiyagoda 1991). A. parvus is available in both lotic and lentic systems in the low country wet, intermediate and dry zones both in moderately saline and freshwaters. It is a surface feeding, hardy and adaptable predator (Pethiyagoda 1991).

The successes of adoption of $A$. parvus as a biological control agent rely on detailed knowledge regarding the temporal fluctuations of feeding and prey selectivity and synchronizations between prey availability at active feeding of the fish. Since feeding activities of many species are often cyclic, diet composition vary over a 24 hour period (Polacik and Reichard 2010). Accordingly, feeding and food selectivity of $A$. parvus inhabiting abandoned brick pits, which is one of the preferred habitats of $A$. parvus were studied for 24 hour period. 


\section{Materials and Methods}

A. parvus were collected in January 2012 from a brick pit located in Pannala $\left(80^{\circ} 2.5^{\prime}\right.$ $\mathrm{E}, 7^{\circ} 19.7^{\prime} \mathrm{N}$ ) area in the North western province of Sri Lanka. The brick pit was an area of $1992 \mathrm{~m}^{2}$ at full capacity level and a perimeter of $233.1 \mathrm{~m}$ at the time of sampling. A. parvus were collected in 2 hour-intervals starting from 8.30 am to 6.30 am on the following day. Fish were caught by hand nets. In each sampling occasion, 12 fish (males and females) were caught and they were immediately transferred to $10 \%$ buffered formalin for further analysis.

A plankton net $(110 \mu \mathrm{m}$ with the diameter of $26.4 \mathrm{~cm})$ was dragged for $5 \mathrm{~m}$ at each sampling occasion to collect the natural food items and the contents were preserved in 5\% buffered formalin and Lugol's Iodine solution for further analysis (Goswami 2004; Suthers and Rissik 2009).

In the laboratory, the fish were blotted and weighed using an analytical balance to an accuracy of $0.1 \mathrm{mg}$. Standard length and total length were measured. Then each fish was carefully dissected and the gut of fish was taken out. The gut length was measured up to nearest millimeter with a measuring board and weight was measured to an accuracy of $0.1 \mathrm{mg}$ using an analytical balance. Gut fullness (fraction filled out of 10 parts) and sex of each individual were also recorded. Gut was then placed in a watch glass and dissolved with $1 \mathrm{ml}$ of distilled water and the contents were then transferred to a Sedgewick Rafter cell. Common copepod was taken as the arbitrary unit. The total number of food particles (Hyslop 1980) in each gut was recorded to the order level (Fernando 1990). Relative gut weight [(gut weight/total fish weight $\times 100$ ], time of peak feeding for each sex, contribution of each food type at different time intervals were compared using one way ANOVA.

Water samples were also examined using the standard procedures of dilution and were examined by Sedgewick Rafter cell method (Suthers and Rissik 2009) to record the food items available in brick pit Index of prey selectivity was calculated as follows:

$$
\mathrm{L}_{\mathrm{i}}=\mathrm{r}_{\mathrm{i}}-\mathrm{p}_{\mathrm{i}}
$$

Where $\mathrm{L}_{\mathrm{i}}$ is the index of prey selectivity for the taxon $\mathrm{i}, \mathrm{r}_{\mathrm{i}}$ is the relative abundance of prey item in the fish gut and $\mathrm{p}_{\mathrm{i}}$ is the relative abundance of the food item in the water body (Zandona et al. 2011). MINITAB 14 and GenStat Release 12.2 statistical software packages were used in data analysis.

\section{Results}

Diet of A. parvus consisted of adult or larval stages of class Insecta (Figs 1a, 1b and 1c) class Maxillopoda (Fig. 1d) and plant parts. Both adult and larval stages of Coleopterans (Fig. 1a) and hymenopterans (Fig. 1b) were detected as insects. In terms of prey abundance, $79.9 \%$ were insect adults, $4.3 \%$ were insect larvae, $4.3 \%$ were copepods and $11.49 \%$ were other food items (plant parts, eggs, detritus and unidentified material (Figure 2). The highest number of average food items was detected during day time around 1230 hrs (Fig. 3). 
(a)

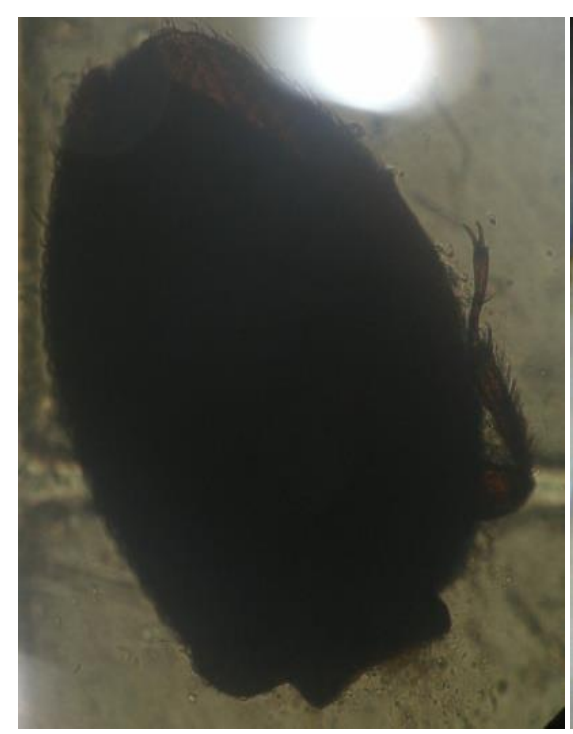

(c)

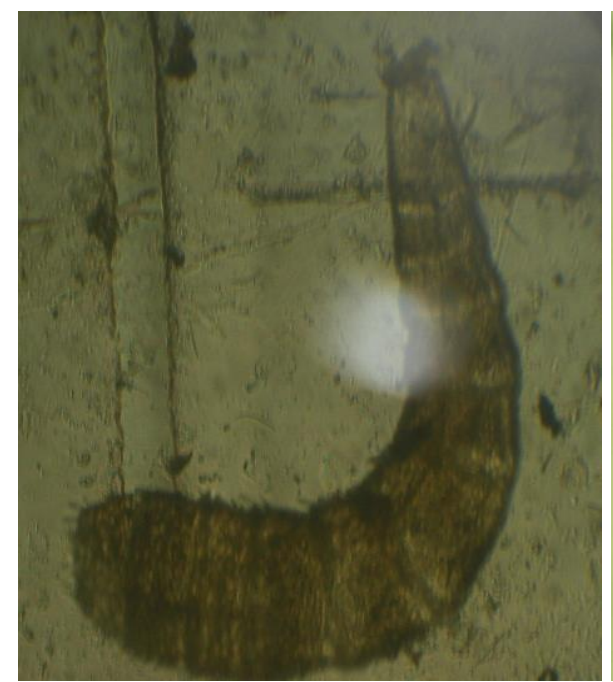

(b)

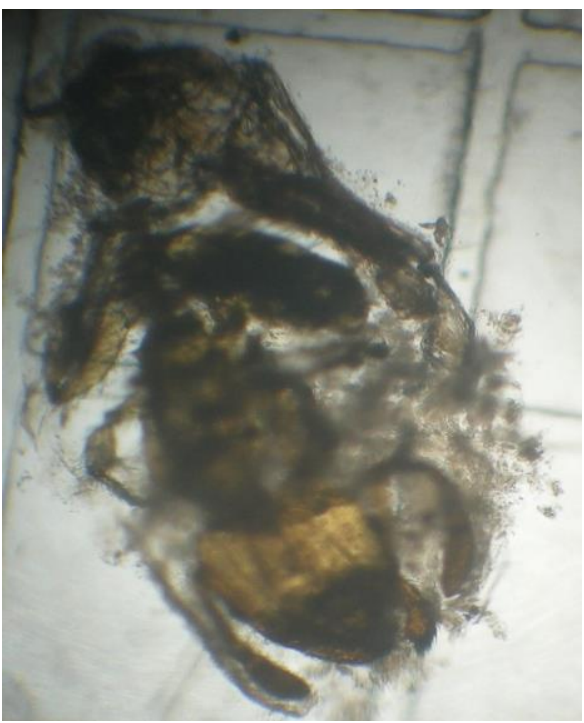

(d)

Figure 1. (a) Hymenopteran ( $\times 4)$; (b) Coleopteran ( $\times 4)$; (c) Insect larval stage $(\times 10)$; (d) Copepod $(\times 10)$ 


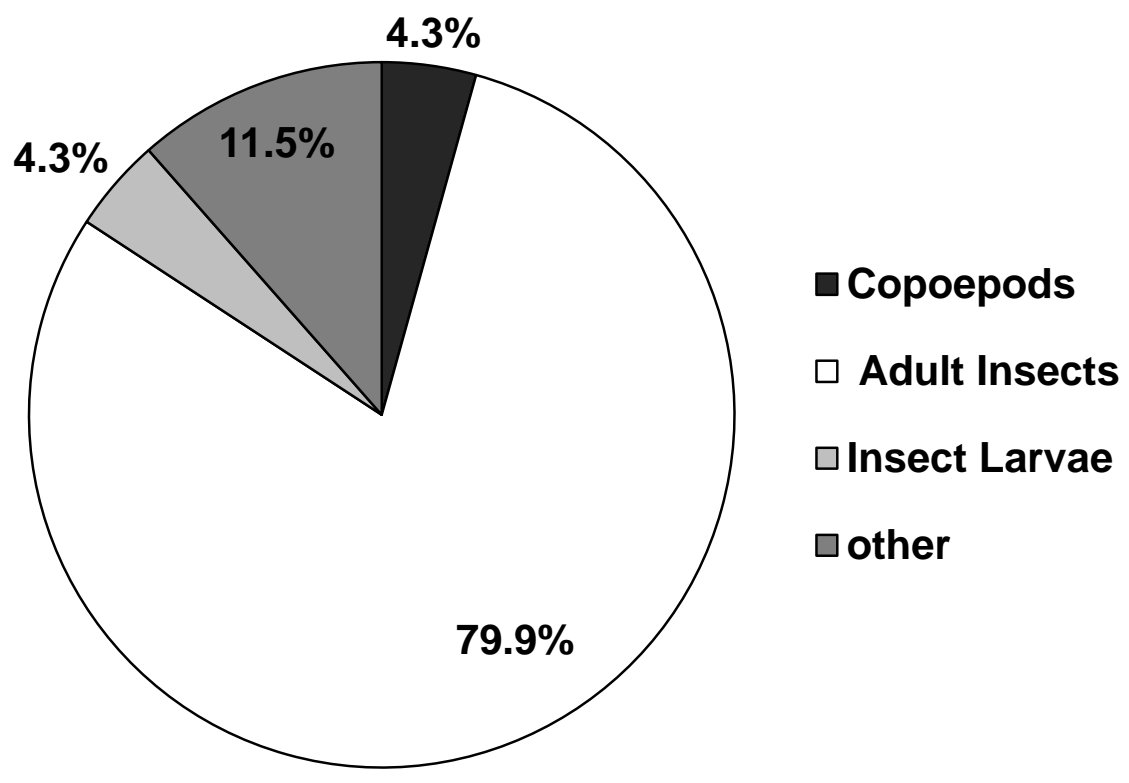

Figure 2. Percentage contribution of food items in the gut content of A. parvus.

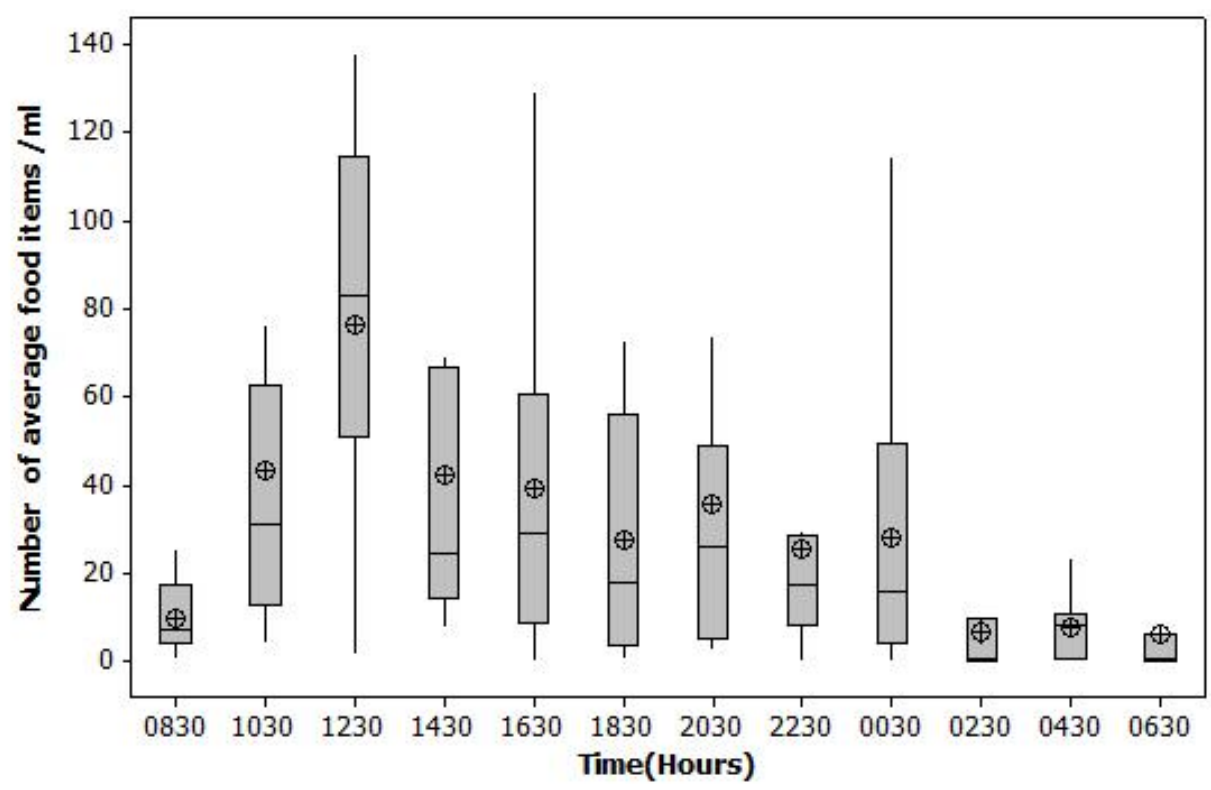


Figure 3. Fluctuations in number of average food items with time. The box plot whiskers depict the range and circled crosses depict the mean at each time.

The gut had a higher fullness ratio during day time (4.3 \pm 0.121$)$ compared to night $(2.4 \pm 0.120)(\mathrm{p}<0.001)$ (Fig. 4). The males had peak gut fullness at 1630 hours (Fig. 4). In the case of females; there were two peak feeding times, one at around 1230 and the other at around 1830. The gut fullness of both male and female decreased towards night.

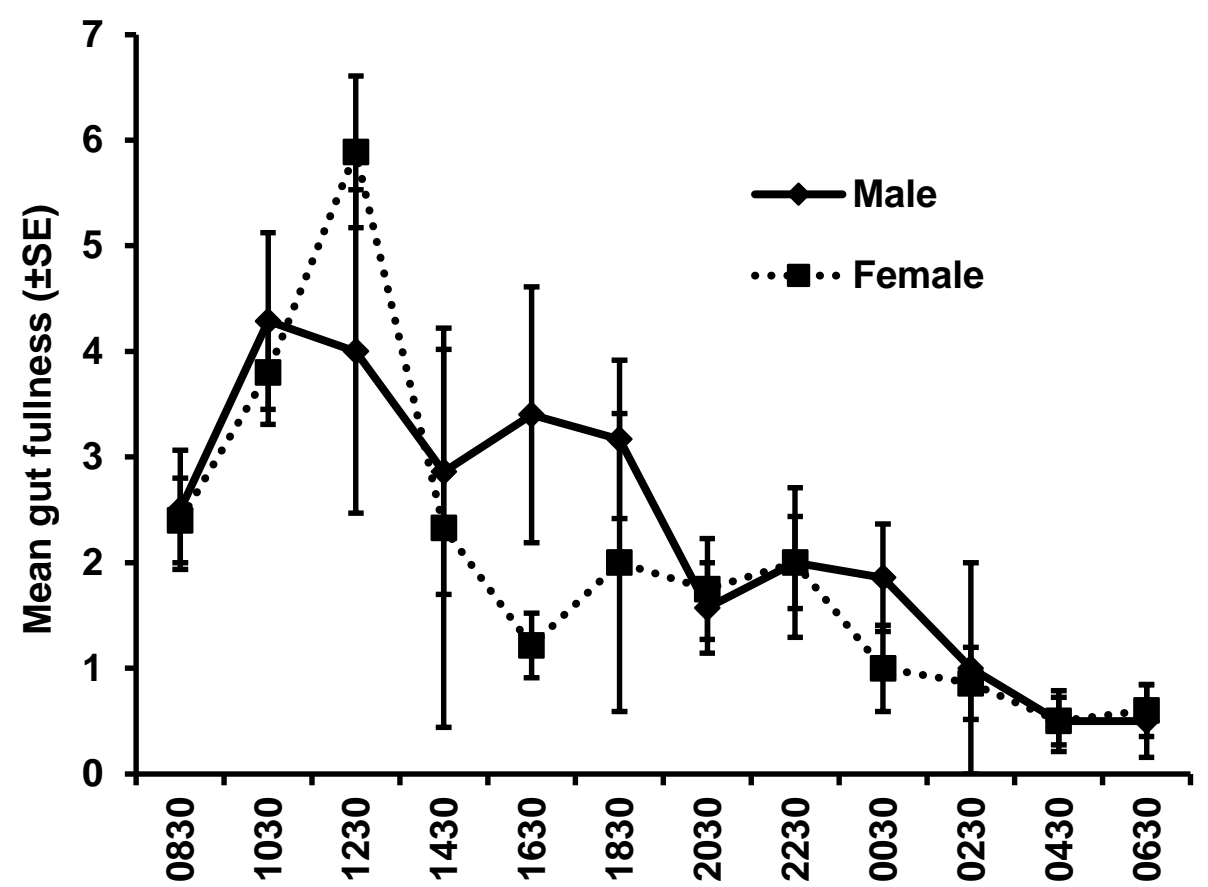

Figure 4. Fluctuations in mean gut fullness $( \pm$ SE) with time for females and males.

In the gut contents, copepods were detected mostly during late morning (8301030) $(\mathrm{p}<0.001)$, whilst insect parts and coleopterans were present at all time periods $(\mathrm{p}<0.001)$. Insect larval stages were detected mostly at 0830 (Fig. 5). 


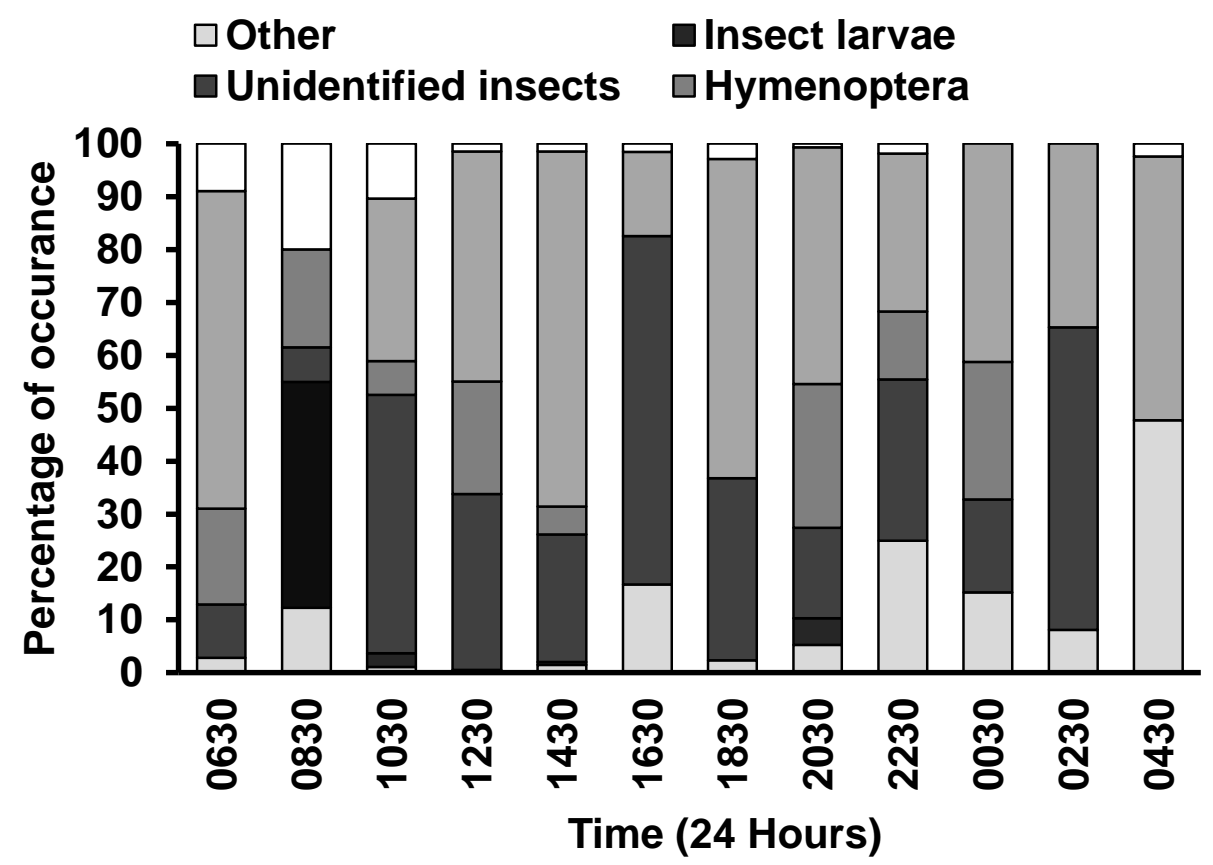

Figure 5. Diurnal variations of the abundance of different food types in the gut content.

Abundance of main food items detected in the plankton samples were copepods, filamentous algae and Coleopteran parts respectively. No Hymenopteran or insect larval stages were detected in sampled water although these food items were present in the gut.

\section{Discussion}

The gut content of A. parvus revealed the opportunities exploited by this species in term of food selection due to its surface living nature. Diet consisted clearly of both aquatic and terrestrial food items such as hymenopterans. Similar results were also found for killifish species Rivulus marmoratus by Taylor (1992) where fish collected from east central Florida had comparative amounts of mosquito larvae.

Polacik and Reichard (2010) reported that the diet of three killifish (Nothobranchius sp.) comprised largely of aquatic invertebrates. Similarly, banded killifish (Fundulus diaphanus) (Johnson and Dropkin 1993), blue fish (Pomatomus saltatrix) (Friedland et al. 1988) and Aplocheilus lineatus (Jacob and Nair 1982) are known to consume insects as their diet .Hence it could be concluded that A. parvus displays insectivorous nature in abandoned brick pits.

There is no direct reason identified for the difference of the peak gut fullness of male and female observed in this study. Also such differences were rare in literature. As Izquierdo et al. (2001) mentioned that egg quality and fecundity depend on nutritional intake. Green et al. (1984) also indicated that male cunners 
(Tautogolabrus adspersus) feed significantly less often than females and concentrate their feeding activity to morning, whilst females feed as frequently in the afternoon as in the morning. However, an interaction between sex and peak feeding among fish is little explored.

It is clearly seen that most of the commonly available food items found in the water body were not found in the A. parvus guts which indicates the nature of active selectivity of prey. Fish seldom ingest prey in proportion to their abundance in the environment. A substantial amount of literature demonstrates that many freshwater and marine fish species selectively feed on relatively large prey (Schabetsberger et al. 2003). According to the Clements and Livingston (1984), patterns of the prey selectivity are the result of predator preferences and /or differences in prey accessibility. As such, it is clear that $A$. parvus is a highly selective and mainly prefer insect borne diets. In A. parvus stomach fullness peaked during morning hours and reached a minimum at night, suggesting a predominantly diurnal feeding pattern. The fish species feeding on adult insects such as Hyporamphus gaimardi, Rasbora danicoius are also mainly have high gut fullness around noon (Piet and Guruge 1997) which supports our finding further. Due to the nature of the diurnal feeding and surface predation, highly selectivity on insects, many species had been used in mosquito control programs. Chandra et al. (2008) described the use of several surface feeding predators such as Aplochilus blockii, A. lineatus, A. panchax in controlling malaria larvae. Ghosh et al. (2011) indicated that the important of using surface feeding predators like Poecilia reticulata and Gambusia affinis in chikungunya vector control programs. Further the patentability of annual killifish, Nothobranchius guentheri on mosquito control in temporary water bodies was proposed by Matias and Adrias (2010) due to surface living and insectivore nature of these fishes.

In summary, this study demonstrates that, A. parvus selectively preys on insects Therefore we can suggest this species as a potential candidate for mosquito vector control. However, further studies have to be carried out to confirm their preference for mosquito larvae in natural environment.

\section{Acknowledgement}

The study was carried out as a part of a research project funded by Global Fund to fight AIDs, Tuberculosis and Malaria (GFATM). BOBLME and SLAFAR are acknowledged for science writing workshop during which this manuscript was prepared.

\section{Reference}

Alkahem, H.F., A.A. Al-Ghanim \& Z. Ahmad 2007. Studies on feeding ecology of aailfin molly (Poecilia latipinnd) dwelling in Wadi Haneefah Stream, Riyadh. Pakistan Journal of Biological Sciences 10(2): 335-341. doi:10.3923/pjbs.2007.335.341 
Awasthi, M., D.N. Das \& R.K. Singh 2006. Qualitative algal analysis from the fishgut: Tested in the rice fish cropping system. International Journal of Environment 3(1): 89-94.doi: 10.1007/BF03325911

Banaru, D. \& M. Harmelin-Vivien 2009. Feeding behavior of Black Sea bottom fishes: Did it change over time? Acta Oecologica 35(6): 769-777. doi:10.1016/j.actao.2009.08.003

Chandra, G., I. Bhattacharjee, S.N. Chatterjee \& A. Ghosh 2008. Mosquito control by larvivorous fish. Indian Journal of Medical Research, 127(1): 13-27.

Clements, W.H. \& R.J. Livingston 1984. Prey selectivity of the fringed filefish Monacanthus ciliatus (Pisces: Monacanthidae): Role of prey accessibility. Marine ecology progress series. Oldendorf 16(3): 291-295.

Day, R.D., D.P. German \& I.R. Tibbetts 2011. Why can't young fish eat plants? Neither digestive enzymes nor gut development preclude herbivory in the young of a stomach less marine herbivorous fish. Comparative Biochemistry and Physiology Part B: Biochemistry and Molecular Biology, 158(1): 23-29. doi:10.1016/j.cbpb.2010.09.010

Fernando, C.H. 1990. The freshwater fauna and fisheries of Sri Lanka. Natural Resources, Energy and Science Authority of Sri Lanka. 444 pp.

Frenkel, V. \& M. Goren 2000. Factors affecting growth of killifish, Aphanius dispar, a potential biological control of mosquitoes. Aquaculture 184(3): 255-265. doi: 10.1016/S0044-8486(99)00326-9

Friedland, K.D., G.C. Garman, A.J. Bejda, A.L. Studholme \& B. Olla 1988. Interannual variation in diet and condition in juvenile bluefish during estuarine residency. Transactions of the American Fisheries Society 117(5): 474-479. doi:10.1577/1548-8659(1988)117<0474:IVIDAC > 2.3.CO;2

Goswami, S.C. 2004. Zooplankton Methodology, Collection and Identification - A Field Manual. National Institute of Oceanography. drs.nio.org/drs/handle/2264/95 16 p.

Ghosh, S.K., P. Chakaravarthy, S.R. Panch, P. Krishnappa, S. Tiwari, V.P. Ojha \& A.P. Dash 2011. Comparative efficacy of two poecilid fish in indoor cement tanks against chikungunya vector Aedes aegypti in villages in Karnataka, India. BMC Public Health, 11(1): 1-8. doi:10.1186/1471-2458-11-599.

Goonatilake, S. 2012. The Taxonomy and conservation status of the freshwater fishes in Sri Lanka. 77-87 pp. In: Weerakoon, D.K. \& Wijesundara (eds), The National Red List 2012 of Sri Lanka; Conservation Status of the Fauna and Flora. Ministry of Environment, Colombo, Sri Lanka.

Green, J.M., G. Martel \& D.W. Martin 1984. Comparisons of the feeding activity and diets of male and female cunners Tautogolabrus adspersus (Pisces: Labridae). Marine Biology 84(1): 7-11. doi: 10.1007/BF00394521

Hyslop, E.J. 1980. Stomach contents analysis - A review of methods and their application. Journal of Fish Biology 17(4): 411-429. doi: 10.1111/j.10958649.1980.tb02775.x

Izquierdo, M.S., H. Fernandez-Palacios \& A.G.J. Tacon 2001. Effect of broodstock nutrition on reproductive performance of fish. Aquaculture 197(1): 25-42. doi: 10.1016/S0044-8486(01)00581-6 
Jacob, S.S. \& N.B. Nair 1982. Food and feeding habits of the larvivorous fish Aplocheilus lineatus (Cuv. \& Val.) in its natural habitat. Journal of Fish Biology 20 (3): 329-339. doi: 10.1111/j.1095-8649.1982.tb04715.x

Jayaratne, R. \& T. Surasinghe 2010. General ecology and habitat selectivity of freshwater fishes of the Rawan Oya, Kandy, Sri Lanka. Sabaragamuwa University Journal 9(1): 11-43. doi:10.4038/suslj.v9i1.3732.

Johnson, J. H. \& D.S. Dropkin 1993. Diel variation in diet composition of a riverine fish community. Hydrobiologia 271(3): 149-158. doi: 10.1007/BF00005412

Konradsen, F., F.P. Amerasinghe, W.V.D. Hoek \& P.H. Amerasinghe 2000. Malaria in Sri Lanka: current knowledge on transmission and control. International Water Management Institute, Colombo. 77pp.

Kumar, R. \& J.S. Hwang 2006. Larvicidal efficiency of aquatic predators: A perspective for mosquito biocontrol. Zoological Studies-Taipei 45(4): 447466.

Kumar, V.V., A.D. Reddy, C. Balakrishna, Y. Satyanarayana \& S.K. Das 2012. Analysis of diet composition, feeding dynamics and proximate composition of Bombay duck, Harpodon nehereus along Sunderban area of West Bengal, India. Achieves in Applied Science Research 4(2): 1175-1182.

Kweka, E.J., G. Zhou, T.M. Gilbreath, Y. Afrane, M. Nyindo, A.K. Githeko \& G. Yan 2011. Predation efficiency of Anopheles gambiae larvae by aquatic predators in western Kenya highlands. Parasit Vectors 4(1): 1-7. doi:10.1186/1756-3305-4-128

López-Peralta, R.H. \& C.A.T. Arcila 2002. Diet composition of fish species from the southern continental shelf of Colombia. Naga, World Fish Center Quarterly 25(3-4): 23-29.

Louca, V., M.C. Lucas, C. Green, S. Majambere, U. Fillinger \& S.W. Lindsay 2009. Role of fish as predators of mosquito larvae on the floodplain of the Gambia River. Journal of Medical Entomology 46(3): 546-556. doi:10.1111/j.16006143.2008.02497.x.Plasma

Matias, J.R. \& A.Q. Adrias 2010. Research The use of annual killifish in the biocontrol of the aquatic stages of mosquitoes in temporary bodies of fresh water; a potential new tool in vector control. Parasites and Vectors 3(1), 1-9. doi:10.1186/1756-3305-3-46

Pethiyagoda, R. 1991. Freshwater fishes of Sri Lanka: Wildlife Heritage Trust of Sri Lanka, Colombo. 362pp.

Piet, G.J. \& A.H.P. Guruge 1997. Diel variation in feeding and vertical distribution of ten co-occurring fish species: consequences for resource partitioning. Environmental Biology of Fishes 50: 293-307.

Polacik, M. \& M. Reichard 2010. Diet overlap among three sympatric African annual killifish species Nothobranchius spp. from Mozambique. Journal of Fish Biology 77(3): 754-768. doi:10.1111/j.1095-8649.2010.02717.x 
Schabetsberger, R., C.A. Morgan, R.D. Brodeur, C.L. Potts, W.T. Peterson \& R.L. Emmett 2003. Prey selectivity and diel feeding chronology of juvenile chinook (Oncorhynchus tshawytscha) and coho (O. kisutch) salmon in the Columbia River plume. Fisheries Oceanography 12(6): 523-540. doi:10.1046/j.13652419.2003.00231.x

Shallof, K.A. \& N. Khalifa 2009. Stomach Contents and Feeding Habits of Oreochromis niloticus (L.) From Abu-Zabal Lakes, Egypt. World Applied Sciences Journal 6(1): 1-5.

Sivadas, M. \& M.M. Bhaskaran 2009. Stomach content analysis of the Indian mackerel Rastrelliger kanagurta (Cuvier) from Calicut, Kerala. Indian Journal of Fisheries 56(2): 143-146.

Suthers, I. \& D. Rissik (eds) 2009. Plankton: A guide to their ecology and monitoring for water quality. CSIRO Publishing. 273pp.

Taylor, D.S. 1992. Diet of the killifish Rivulus marmoratus collected from land crab burrows, with further ecological notes. Environmental Biology of Fishes 33(4): 389-393. doi: 10.1007/BF00010951

Xie, P. 2001. Gut contents of bighead carp (Aristichthys nobilis) and the processing and digestion of algal cells in the alimentary canal. Aquaculture 195: 149-161.

Zandona, E., S.K. Auer, S.S. Kilham, J.L. Howard, A. Lopez-Sepulcre, M.P. O'Connor \& D.N. Reznick 2011. Diet quality and prey selectivity correlate with life histories and predation regime in Trinidadian guppies. Functional Ecology 25(5): 964-973. doi:10.1111/j.1365-2435.2011.01865.x 